such devices as air-purification respirators when caring for patients with proven or suspected TB. However, we believe that the local hospital registry can and should be a focal point for determining the extent to which such measures are necessary at individual institutions. Perhaps more importantly, we believe that the registry is a logical focal point for determining that existing infection control recommendations are being carried out and that patients released from the hospital are not lost to follow-up. Infection control personnel are in a position to work with physicians, hospital staff, and health departments to ensure that this ancient enemy is confronted forcefully, one case at a time.

\section{REFERENCES}

1. Centers for Disease Control. A strategic plan for the elimination of tuberculosis in the United States. MMWR 1989;38(suppl S-3): $1-25$.

2. American Thoracic Society. Control of tuberculosis in the United States. Am Rev Respir Dis 1992;146:1623-1633.

3. Reichman LB. The U-shaped curve of concern. Am Rev Respir Dis 1991;144:741-742. Editorial.

4. Braun MM, Cote TR, Rabkin CS. Trends in death with tuberculosis during the AIDS era. JAMA 1993;269:2865-2868.

5. Hopewell P. Tuberculosis and infection with the human immunodeficiency virus. In: Reichman LB, Hershfield ES, eds. Tuberculosis: A Comprehensive International A pproach. N ew York, NY: Marcel Dekker Inc; 1993:369-394.

6. Joseph S. Tuberculosis, again. A m J Public H ealth 1993;83:647648. Editorial.

7. Dooley SW, Jarvis WR, Mar-tone WJ, Snider DE. Multidrugresistant tuberculosis. Ann Intern M ed 1992;117:257-259. Editorial.

8. Beck-Sague C, Dooley SW, Hutton MD, et al. Hospital outbreak of multidrug-resistant $M$ ycobacterium tuberculosis infections. JAMA 1992;268:1280-1286.

9. Frieden TR, Sterling T, Pablos-Mendez A, Kilburn JO, Cauthen GM, Dooley SW. The emergence of drug-resistant tuberculosis in New York City. N Engl J M ed 1993;328:521-526.

10. Glassroth J. Tuberculosis in the United States: looking for a silver lining among the clouds, Am J Respir Dis 1992;146:278-279. Editorial.

11. Ryan F. The Forgotten Plague: H ow the Battle A gainst Tuberculo- sis Was Won-and Lost. Boston, MA: Little, Brown and Co; 1992:389-417.

12. Centers for Disease Control. National multiresistant tuberculosis task force. National plan to combat multidrug-resistant tuberculosis. M M WR 1992;41(RR-11):1-48.

13. Snider DE, Roper WL. The new tuberculosis. N Engl $J$ M ed 1992;326:703-705. Editorial.

14. McGowan JE Jr. Resurgent nosocomial tuberculosis: consequences and actions for hospital epidemiologists. Infect Control Hosp Epidemiol 1992;13:575-578. Editorial.

15. Centers for Disease Control. Draft guidelines for preventing the transmission of tuberculosis in health care facilities, 2nd ed. Federal Register 1993;58:195(Part 2);58 FR 52810, October 12, 1993.

16. MacGregor RR. A year's experience with tuberculosis in a private urban teaching hospital in the postsanatorium era. $\mathrm{Am} \mathrm{J}$ M ed 1975;58:221-228.

17. Bryan CS. The hospital tuberculosis registry: an aid to infection control. Am J Infect Control 1983;11:57-62.

18. Furey WW, Stefancic ME Tuberculosis in a community hospital: a five-year review. JAMA1976;235:168-171.

19. Edlin GP. Active tuberculosis unrecognized until necropsy. Lancet 1978;1:650-652.

20. Finch RG, Cope JR. Unsuspected tuberculosis in genera1 hospitals. Lancet 1973;1:1496-1499.

21. Rosenthal T, Pitlik S, Michaeli D. Fatal unrecognized tuberculosis in hospitalized patients. /Infect D is 1975;131:S51-S56.

22. Rust RE. Tuberculosis in the 1990s: resurgence, regimens, and resources. South M ed $J$ 1992;85:584-593.

23. Bryan CS. Unread tuberculin tests. JAMA 1980;244:1126.

24. Huebner RE, Schein ME Bass JB Jr. The tuberculin skin test. Clin Infect D is 1993;17:968-975.

25. Cox JN, Brenner ER, Bryan CS. Changing patterns of mycobacterial disease at a teaching community hospital. Infect Control Hosp Epidemiol 1994;15:513-515.

26. Schluger NW, Kinney D, Harkin TJ, Rom WN. Clinical utility of the polymerase chain reaction in the diagnosis of infections due to M ycobacterium tuberculosis. Chest 1994;105:1116-1121.

27. Hopewell PC. Impact of human immunodeficiency virus infection on the epidemiology, clinical features, management, and control of tuberculosis. JAMA 1992;2678:2632-2635.

28. Iseman MD, Cohn DL, Sbarbaro JA. Directly observed treatment of tuberculosis: we can't afford not to try it. $\mathrm{N}$ Engl $\int \mathrm{M}$ ed 1993;328:576-578. Editorial.

29. Centers for Disease Control. Guidelines for preventing the transmission of tuberculosis in health care settings, with special focus on HIV-related issues. M M WR 1990;39(RR-17):1-29.

\title{
High Prevalence of HIV-Positive Blood Samples Pose Risk to Laboratory Technologists
}

\section{by Gina Pugliese, RN, MS Medical News Editor}

Researchers from the Centers for Disease Control and Prevention found a $2 \%$ prevalence of HIV-1 among 55,613 specimens submitted to 10 large com- mercial laboratories by general internists, pediatricians, and family practitioners. The prevalence among different laboratories varied 50-fold from 0.3 to $12.4 \%$ and the prevalence was not always consistent with the AIDS incidence served by the laboratories. The survey sample did not include specimens from high-risk specialties, such as infectious disease.

FROM: Fernando NH, et al. Journal of AIDS 1994;7:177-181. 